\title{
Non-Muslim Pakistanis' Loyalties and their Services for Interfaith Harmony in Pakistan
}

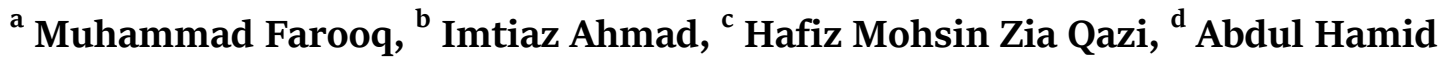

${ }^{a}$ Assistant Professor Department of Islamic Studies, Government Graduate College Gojra, Pakistan

${ }^{\mathrm{b}}$ Department of Islamic Studies, University of Okara, Pakistan

Email: imtiazahmedo10@gmail.com

${ }^{\mathrm{c}}$ HOD Islamic Studies AMBLEM Education System Rawalpindi, Pakistan

${ }^{\mathrm{d}}$ LT.CDR(R) Pakistan Navy, Lecturer Department of Islamic Studies, Bahria University Islamabad, Pakistan

\begin{tabular}{l}
\hline ARTICLE DETAILS \\
History: \\
Accepted 15 March 2021 \\
Available Online 31 March 2021
\end{tabular}

Keywords:

Pakistan; Non-Muslims;

Interfaith harmony; Services;

Loyalties

JEL Classification:

N15

DOI: 10.47067/real.v4i1.119

\begin{abstract}
Loyalty and reliability have always been the aim of high ranked societies, striving for better living. Loyalty and reliability are like a flower that blooms out of pleasant and friendly atmosphere, found online people with similar mind-sets, wanting to achieve prosperous goals. Envy, hatred and jealousy don't give loyalty a chance to flourish instead, they remove it immediately. This passion only grows and propagates in the atmosphere of love, kindness and great heartedness, while it withers away and ends slowly in the hostile environment. Every citizen in Pakistan is a servant and well-wisher of Pakistan. The loyalty of Muslim community is appreciable at its place, but non-Muslim citizens are also heading forward in serving Pakistan. It is only through this unity that the conditions of stress and misconceptions can be eliminated among one another. In this article, in the historical context of Pakistan, it is sought to clarify that non-Muslims of Pakistan, like the Muslim citizens of Pakistan, are loyal and faithful to Pakistan and love the soil of their homeland, so that their haters get involved in the color of love, and the fortunes of mutual misunderstandings can be eliminated and the honorable citizens of Pakistan can promote peace and prosperity for Pakistan.
\end{abstract}

(C) 2021 The authors. Published by SPCRD Global Publishing. This is an open access article under the Creative Commons Attribution-

NonCommercial 4.0

\section{Introduction}

Loyalty means devotion and respect towards a nation, purpose, philosophy, country, group, or individual (Collins English Dictionary, 2018). In law and politics it is defined as "the loyalty of an individual towards a nation, whether he/she is born in it or has taken an oath while living in it". In fifteenth century the word of loyalty was used for service, affection or oath, whereas, in sixteenth century, according to Britannica, it became a Lex (Latin) from loialte (French) which means "law" (Encyclopedia Britannica Cambridge University Press, 17 (11th ed). 
Loyalty means adhesion, allegiance, attachment, commitment, constancy, dedication, devotedness, devotion, faith and faithfulness (Dahlavi,1898).Knowing oath is also necessary regarding about loyalty. From the beginning of Pakistan's history till date, non-Muslim minorities have been an important part of our lives. From the profession of education to national defence, despite being in minor count, they are not less than the majority in any case. But unfortunately, instead of shedding light on their role, the course of time has covered them with the dust of prejudice. With every passing day and after hearing about every day incidents, the identity of non-Muslims, as a nation, is becoming serious issue within Pakistanis as if the term 'Pakistani' is a person associated with a particular religion, but in fact, every person who took birth in this land and every person who calls himself a patriot, whether he is Christian, Hindu, Paris or Sikh is as much as Pakistani as a Muslim. The love of country is undoubtedly an undeniable fact. It is a natural phenomenon. A person develops a deep sense of love and faith for the soil where he is born.

\section{Loyalty towards Pakistan, its constitution and law}

Oaths and declarations can vary apparently but infact, a person can never think of betraying his motherland. The role of non-Muslims regarding loyalty towards Pakistan and its constitution cannot be denied. Under Article 5 of the constitution of Pakistan, it is compulsory for every Pakistani to be faithful to Pakistan irrespective of any cast, sect, religion or nationality. It is a constitutional and magisterial right that every citizen is bound to follow. It has been mentioned in Article 5 of the Law that:

1. Loyalty towards the country is a fundamental obligation of every citizen

2. The obedience of law and rules is obligatory for every citizen to follow whether he/she is in Pakistan or anywhere else (The constitution of the Islamic republic of Pakistan, Article 5).

After understanding the term loyalty, it is necessary to know about oath. It is important to clarify its significance through few examples so that the misconceptions between Pakistani Muslims and Non-Muslims regarding loyalty towards Pakistani borders and constitution can be resolved.

\subsection{Definition of oath}

a(1): a solemn usually formal calling upon God or a god to witness to the truth of what one says or to witness that one sincerely intends to do what one says

(2): a solemn attestation of the truth or inviolability of one's words

b: something (such as a promise) corroborated by an oath

2: an irreverent or careless use of a sacred (Dahlavi, 1898).

In Simple words to ensure justice to the responsibilities of one's position is called oath. Sometimes, words such as oath, confession, affirmation and recognition are commonly used as synonyms, while in fact they are legally related to each other, they have different legal effects. The example can be found in the Oath Act 1883. In case of objection for the oath, non-Muslim will accept it because legal consequences are there for the transformation of oath from acceptance. In the Oath Act, 1873, it is written that in case of objection for the oath, non-Muslim will accept it because legal consequences are there for the transformation of oath from acceptance. For instance, a lie against false oaths is punishable, while false confession is not a criminal act.

All the officials and members of government of Pakistan, including President, Prime Minister, members of National Assembly, members of Senate, governors, judges, election commissioners, armed forces of the state take oath in front of the Prophet (peace and blessings of Allah be upon him) and people of the world, Almighty Allah, that they will maintain peace, prosperity, and maintain Islamic 
ideology in Islamic Republic of Pakistan. Words of the oaths of the President, Prime Minister, Ministers and Chief Ministers of the State and heads of different departments are somewhat similar. What does these oaths consists of? Below are some examples of oaths of important figures in Pakistan.

\subsection{President}

In the name of Allah (the most Beneficent, the most Merciful)

I, ..................., do solemnly swear that I am a Muslim and believe in the Unity and Oneness of Almighty Allah, the Books of Allah, the Holy Quran being the last of them, the Prophet hood of Muhammad (peace be upon him) as the last of the Prophets and that there can be no Prophet after him, the Day of Judgment and all the requirements and teachings of the Holy Quran and Sunnah...............May Allah Almighty help and guide me. A'meen (The constitution of the Islamic republic of Pakistan, Third Schedule, 2017).

\subsection{Prime Minister}

In the name of Allah (the most Beneficent, the most Merciful)

I, .............., do swear solemnly that I am a Muslim and believe in the Unity and Oneness of Almighty Allah, the Books of Allah, the Holy Quran being the last of them, the Prophet hood of Muhammad (peace be upon him) as the last of the Prophets and that there can be no Prophet after him............shall become known to me as Prime Minister except as may be required for the due discharge of my duties as Prime Minister. May Allah Almighty help and guide me. A'meen (The constitution of the Islamic republic of Pakistan, Third Schedule, 2017).

\subsection{Chief Justice of Pakistan or Judge of the Supreme Court and/or High Court}

In the name of Allah (the most Beneficent, the most Merciful)

I, ....................., do solemnly swear that I will bear true faith and allegiance to Pakistan: That, as Chief Justice of Pakistan or a Judge of the Supreme Court of Pakistan or Chief Justice or a Judge of the High Court for the Province or Provinces. .And that, in all circumstances, I will do right to all manner of people, according to law, without fear or favour, affection or ill-will. May Allah Almighty help and guide me. Ameen (The constitution of the Islamic republic of Pakistan, Third Schedule, 2017).

\subsection{Members of the Armed Forces}

In the name of Allah (the most Beneficent, the most Merciful)

I, ..........., do solemnly swear that I will bear true faith and allegiance to Pakistan and uphold the Constitution of the Islamic Republic of Pakistan which embodies the will of the people.............and under the law. May Allah Almighty help and guide me. A'meen (The constitution of the Islamic republic of Pakistan, Third Schedule, 2017).

The oath or affirmation should not confiscate anyone's rights, otherwise, the objections of nonMuslims would prove to be true that Pakistan is a country where it is difficult for non-Muslim minorities to live, but how can a state that is built on the basis of Islam can cause hindrance in the rights of non-Muslims, whereas Islam had an ambition for rights when no one was even aware of the word of 'Rights. From the judiciary, administration and legislation to the Union Council, everywhere the role of non-Muslim minorities appears to be significant, their loyalty can be seen. Often times, protests and slogans against government of the time are considered contradictory against the country and the constitution, whereas, they are two different dimensions. Opposing the government does not indicate one's loyalty, if one does so, then it is beyond reason, wisdom and the law. If any person is involved in treason against the country and its constitution, then he/she is imposed serious offense on the basis of Article 6 of the constitution, whether he/she is Muslim or non-Muslim. 
The content of the oath of the Prime Minister and the President emphasizes the importance of Islamic beliefs rather than pledging loyalty to the country. And this should also be the case because the country has Muslim majority, and it was founded on the ideology of Islam, and this is according to the traditions of international and democratic system.

\section{Interfaith Harmony}

Harmony is a combination of two words i.e. "we" and "harmony", and "we" refers to my companion. This is a conjunction word which is used as prefix which means partner, companion, spouse and equality in status (Serhanddi, 1983). In short harmony is combining two or more objects in a co-ordinate way, to bring level of equality/equilibrium, closeness, reconciliation, harmony and spirit of deception for maintaining justice.

\section{The Loyalty of Non-Muslim Pakistani Citizens with Pakistan}

The sacrifices of non-Muslim citizens can never be overlooked. Unfortunately, their sacrifices are nowhere to be found in our textbooks, and because of this, our new generation is not aware of this fact, and they have doubts regarding non-Muslims' loyalties whereas, non-Muslim citizens are loyal to their country just as much as a Muslim citizen is, Pakistani non-Muslim citizens have not migrated from Mars, they were born and raised here and they will die here. There are many fields of life where they have set examples of sacrifices. Pakistani non-Muslim citizens have been effectively brought national system, their loyalty has been recognized and laws regarding them have been improvised so that they can serve their country in political and economic fields. Here are few examples which are indicative of loyalty of non-Muslim Pakistanis towards Pakistan and its constitution.

\subsection{Loyalty and services of Pakistani judiciary and non-Muslim citizens}

It is manifest that the Holy Qur'an inter alia enjoins that there is no difference between the individuals of mankind on the basis of race, color and territory and that all human beings are equal in the eyes of Allah. The fittest person who is strong and trustworthy is to be employed. Article27 of the 1973 Constitution: Safeguards against discrimination in services (1) No citizen otherwise qualified for appointment in the service of Pakistan shall be discriminated against in respect of any such appointment on the ground of race, religion, caste, sex, residence or place of birth (The constitution of the Islamic republic of Pakistan, Article 27).

\subsubsection{Loyalty and services of the Pakistani judiciary and Christian citizens}

Christians worked together with Muslim League in Pakistan Movement, even in the Boundary Commission, making it a significant contribution with respect to the ratio of population in the favour of Muslims. In 1947, three Christian members of Punjab Assembly gave their votes in favour of Pakistan. Father F.J. Saldhana even said that it is difficult to claim that it was a decisive vote, but it was a small contribution from us (Salim, 2000).

\subsubsection{Justice A. Cornelius}

He was born on March 1, 1903, in Agra. From 1960 to 1968, he was elected as Chief Justice of the Supreme Court of Pakistan ( ${ }^{\mathrm{N}}$ ews Paper Jang, Lahoor, Golden Jublie, especial, 1997).The role of Justice Cornelius is a great example of loyalty and patriotism in the Dosso Ban Federation of Pakistan case, when the majority accepted the dictator, but Justice Cornelius, being loyal to the country and constitution, considered the act unconstitutional. In 1967, Government of Pakistan gave them the honour of Hilal-ePakistan. 


\subsubsection{Justice R.G.S}

After the formation of Pakistan, the British national, in the form of a judge of the High Court Lahore, did his duties. He was famous for his judgment on the basis of law-based principles (Father-eFrance, 1997).

\subsubsection{Justice Charles Lobo}

He was the judge of Sindh chief court; he represented Pakistan in the United Nations General Assembly (Father-e-France, 1997).

\subsubsection{R. A. Gum}

He was born in 1940, he became a member of the Calcutta Corporation twice and became a member of the United Bengal Legislative Assembly twice. His most important feat was that when he voted in favour of Pakistan on the occasion of division of India (Salim, 2000).

\subsubsection{C.E. Gabon}

He was one of the leaders of Pakistan movement (who worked with Muslim league) with great courage to awaken the minorities for the creation of Pakistan. CE Gabon was the one who made arguments in Pakistan's support as a Christian representative in front of the Boundary Commission. In 1951, he was appointed as a member of Punjab Legislative Assembly. Additionally, he was also elected deputy speaker of Pakistan Legislative Assembly (Salim, 2000).By observing the history of these people; it is clear that how the Christian community is sincere and loyal to Pakistan and its constitution.

\subsubsection{Loyalty and services of Pakistani judiciary and Persian citizens}

Parsi religion is the oldest religion of world, which is considered as a mother of religions. At the time of division of India, almost 5,00o Parasis were inhabited in the areas of Pakistan, who decided to stay in Pakistan, at the assurance of Quaid-e-Azam that their properties would be protected (Dadchanji, ${ }^{1997)) \text {. }}$

Pakistani Parsi citizens have always given evidence of loyalty with Pakistan. Its services cannot be forgotten. Here are some personalities mentioned:

\subsubsection{P.D. Bindara}

In 1951, he was elected as a member of the Punjab Constitutional Assembly on the basis of minorities and members of the paper industry and the establishment committee of the Interior Committee. During flooding in Punjab, he dedicated his library for relief work and gave Prime Minister of Pakistan (Liaquat Ali Khan) 3,000 rupees and 10,00o rupees to Governor Punjab (Salim, 2000).

\subsubsection{Jamshaid N sirwangi Mahta}

On January 7, 1886, He was born in Karachi in a Parsi family. In 1933, for the amendment of the Karachi Municipalities Act, he was nominated as a member of the Bombay Legislative Council. Due to which he took part in the separation movement of Sindh (Salim, 2000). Karachi Social Service Group was established by the efforts of Jamshed $\mathrm{N}$ serwanjee, under which 60 welfare organizations of Karachi were gathered to work jointly ( $\left.{ }^{\text {Habeeb }}, 1995\right)$.

\subsubsection{Justice Darab Patel}

He was born on September 13, 1924 in Quetta. In 1966 he was appointed as judge of the West Pakistan High Court and of the Supreme Court of Pakistan in 1976. Meanwhile, he also had the opportunity to serve as the first Vice Chancellor of Baluchistan University. He was a member of the 
Supreme Court bench which heard the appeal of Zulfiqar Ali Bhutto. In this case, He wrote his dissenting note and recommended the release of Bhutto (http://urdu.abbtakk.tv/43440-stories-aaj-kadin-justice-durab-patel-barsi150315/). Furthermore, FEDesha, Sir Feroz Mehta, KF Nurman, Sir NP Engineer and Homi Supervy have also rendered valuable services in the field of law. $\left({ }^{\text {Dadachan, } 1997}\right)$.

\subsubsection{Loyalty and services of Pakistani judiciary and Hindu citizens}

According to figures, in Pakistan in 1998, their population is around 2.5 million (Government of Pakistan, 1998, op, cit).According to the estimate of Pakistan Council of Hindus, the total population of Hindus is now more than seven million. (Pakistan Hindu Council, 2014). Pakistani Hindu citizens who set examples of loyalty to Pakistan. A few are mentioned below:

\subsubsection{Joginder Nath Mandal}

He belonged to Dalit family of Bengal (Akhtar, 1997).After the elections of 1946, Britishers made a government of five Ministers for India and Pakistan each. Quaid-e-Azam nominated him from Pakistan as a cabinet member, Quaid-e-Azam did not stop here, but on August 10, 1947, when Pakistan's first assembly meeting was held in Karachi, Quaid-e-Azam nominated his as President of the Assembly. When Pakistan's first cabinet was formed, Quaid-e-Azam had made as a Minister of Law of the country (Nsher, 2008). The first law of the Islamic Republic of Pakistan was made by a Hindu minister, and the first draft of the amendment in the rules was also issued from the same sign of the Hindu Dalit. He died in 1968 (Salim, 2000).

\subsubsection{Kumar Das Basant}

He was born in 1883 in Sylhet. He studied law and began regular practice in the Sylhet in 1910. In 1946, he became the minister of Assam Government and after partition of India he became the member of Eastern Bengal Legislative Assembly. In 1955, he was appointed as member of Pakistani constitutional assembly (Salim, 2000).

\subsubsection{Lala Kotoram}

He was born in Lucky Marwat district of Bannu in Munich Khel on 9 September, 1896. In 1914, he passed his matric examination from the Church Mission High School passed with distinction. In 1925, after getting the LLB degree from Punjab University, he started attending the provincial border (Akhtar, 1997). In 1946, he was elected a member of Provincial Assembly on the ticket of Indian National Congress. But on the occasion of division of India, he opposed the National Congress and voted for Pakistan and refused to go to India after Pakistan's creation, (news paper Jang, Rawalpindi, 1997).

\subsubsection{Rana Bhagwan Das}

He was the first Hindu and second non-Muslim judge of the Supreme Court. He was born on 2012-1942, in Naseerabad in Larkanaa district of Sindh province ( Nwa e Waqt, Lahore, Pakistan , 2015) ${ }^{\cdot} \mathrm{He}$ started practicing the law in 1965 and only two years after his practice, he became a part of the judiciary. He was appointed as a civil judge. After 27 years of staying in the subordinate courts, he was appointed as a judge in the Sindh High Court.On February 4, 2004, he was appointed as Supreme Court judge. He was honoured to be the first Hindu judge of the Supreme Court. His appointment was challenged with a claim that a Hindu couldn't serve as a judge of Supreme Court, but this claim was rejected by the Sindh High Court. He was appointed as acting Chief Justice in many instances. In 2007, when the military chief General Pervez Musharraf disqualified Chief Justice Iftikhar Muhammad Chaudhary, He took over the responsibilities of the Chief Justice of Pakistan.After retirement from the Supreme Court, he was appointed as chairman of the Federal Public Service Commission in November 2009 (Nwa e Waqt, 2015). He died on February 23, 2015 (Nwa e Waqt, 2015). 


\subsubsection{Dhirendr Nath Datta}

Born on November 2, 1886 in Brahman Beria District ([A Tribute to this Country]. Prothom Alo (in Bengali), 2007). He was a lawyer and politician. In 1938, he became a member of the Bengal's Legislative Assembly from the platform of Congress (Salim, 2000). Additionally, Pakistani national patriots belonging to the Hindu religion who devoted their lives to the homeland of their beloved institution, and served as the backbone of Pakistan, include Kamini Kumar Dittah, Karpal Das Sreewmal, Kumar Daas Basant, Kumar Dutt Bhupandra, Lala Kotoram and Vander Anath Dittah (Salim, 200o).

\subsection{Non- Muslim Pakistanis' Loyalty and Services for Pakistan in Defence}

Defence of Pakistan is actually possible only with love of homeland and patriotism. Patriotism/love of homeland is a natural thing. Every human loves his country, province, district, city or village, street, house and his room. Such patriotism in Islam is not forbidden. Islam permits everyone to love and express patriotism to country in a legitimate way. As Anas bin Malik (RA) narrates:

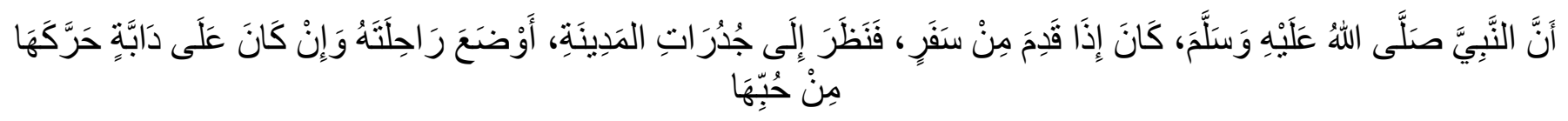

(Sahih al-Bukhari, Hadith no:1886)

Of course, when the Prophet (SAW) used to return from a journey and looked at the walls of Madina, he would hasten the rides (camels) because of the love of Medina, and if he was riding on a cattle (donkey or mule), and he would have run them too.

This patriotism forced every person of the homeland not to bother sacrificing his life for defending the country. Pakistani constitution takes same approach under Article 244 that every person of the armed forces shall take oath as per the phrase given in Table III (The constitution of the Islamic republic of Pakistan, Article 244) and in next article Defense of Pakistan is mentioned as follows:

Under Article 245, Armed Forces, under the directions of the Federal Government, will defend Pakistan against the threat of external aggression or war and, will work under the law in the aid/assistance of civilian authorities when called upon to do so (The constitution of the Islamic republic of Pakistan, Article 245). According to this article, no limit has been specified for Muslim or non-Muslim in defending Pakistan. In Pakistan army institutions, only citizenship from soldier to officer rank is maintained. Affidavit given in Table III of the Constitution of Pakistan states the condition of loyalty to State of Pakistan, with democratic approach and no restrictions of religious or professional bond or pledge, which clarifies that there is no hindrance/barrier for serving in defense agencies like judiciary and legislature. Contrarily, responsibility for rights and loyalty has been imposed according to democratic principles.

To join armed forces in Pakistan, it is necessary to be a Pakistani only. There is no color conscience, no captivity of religion and nation. Under Article 39 "State ensures that People of all regions of the country would have been able to participate in Pakistan's armed forces". (The constitution of the Islamic republic of Pakistan, Article: 39). Non-Muslim citizens have been remained as an important part of our national life from the beginning of Pakistani history up till now. Non-Muslim Pakistani, despite of their numerical underperformance, are in no way less than a Muslim majority regarding their performances and roles in education, science and social services, and defense.

It is necessary to prove tolerance and eliminate the feelings of alienation and deprivation of the religious minorities of the country, and also to indulge them in the hostile/beautiful colors on happy 
aspect of Pakistan, which will be needed to emerge as a steward of freedom, enlightenment and peace in the world. In the Pakistan army, capability from a soldier to an officer rank is only based on the citizenship and the condition of loyalty to the State of Pakistan is mentioned in Article: 5

1- Loyalty to the State is the basic duty of every citizen.

2- Obedience to the Constitution and law is the [inviolable] obligation of every citizen wherever he may be and of every other person for the time being within Pakistan. (The constitution of the Islamic republic of Pakistan as Modified up to the 30 March, 2017, National Assembly of Pakistan, Art: 5).

Non-Muslim citizens also showed their loyalty towards the defence of Pakistan. Some of these personalities are mentioned below:

The valiant and high status of our armed forces is the result of non-Muslim officers, youth, martyrs and war survivors; they served no less than that of a Pakistani Muslim. In reality, Pakistan and Pak Army are the one in which each individual and every provincial and regional background are identical, and he is a patriotic Pakistani.

\subsubsection{Loyalty and services of non-Muslim citizens in the '65 and ' 71 war}

Like the rest of the country, non-Muslim citizens did not show any hesitation in establishing examples of their loyalty towards Pakistan. Non-Muslim citizens are just as much loyal to this country as a Muslim citizen. Here, the loyalty of non-Muslim citizens in both the wars is mentioned.

\subsubsection{Christian's loyalty in wars}

\subsection{Air Vice Marshal Eric Gordon Hall}

Eric Gordon Hall was born to Burmese Christian parents and after joining the Pak Air Force, he lived as a Pakistani citizen. He was a group captain in 1965 war and gave the idea of using C-130 cargo plane as a bomber plane, due to lack of the bomber planes and technical issues ( ${ }^{\text {The News International, Jang Group }}$ of Newspapers, ${ }^{2010}$ ). For this purpose, by flying a C-130 plane, he carried out an exciting bombardment mission, surprising the pilots around the world. He received Sitara-e-Jurat for his war-craft services ${ }^{\text {The }}$ News International, Jang Group of Newspapers ${ }^{2010}$ ).

\subsubsection{Wing Commander Marvin Leslie Middle Coat}

He was the heir of a Christian family of Lahore, who was remembered in Pakistan Army as Commander Lesley. He received Sitara-e-Jurrat in 1965 Indo-Pak war for destroying the enemy's invading fighter aircrafts. Maroon Lesley and Peter Christie were the Christian youth who sacrificed their lives in the field of war.

\subsubsection{Loyalty and services of Persian citizens in wars}

\subsection{Lieutenant Colonel MacPiston G Sparywala}

Lieutenant Colonel MacPiston G. Sparywala lead a battalion of Baloch regiment in 1965 and received high praise from President Ayub Khan.

\subsection{Maj. Gen. Czad Safari}

Czad Safari was the first Parsi General of Pakistan Army. His father, Lieutenant Colonel MacPiston G. Sparywala led a battalion of Baloch regiment in 1965 and received high praise from President Ayub Khan. Kayzad Manak underwent the command and staff college course in 1986 .He was awarded Nishaan-e-Imtiaz by General Musharraf in 2002 for his prominent military services.Apart from this, Air Commodore Parsi Veer, Commander F. De Hector (Navy) and Captain Nausher Jahangir 
Cooper (Navy) and similar Parsi officers showed their loyalty to armed forces in various years.

\subsubsection{Loyalty and Services of Sikh Citizens in Wars}

Where Sikhs were thirsty for Muslim blood, but there were some who wanted to join broken hearts. Sardar Kapoor Singh G writes "In May 1928, Mr Jinnah had tried twice to join Master Tara Singh and Maharaja Patiala to establish permanent friendship between Muslims and Sikhs, which is also, more or less, related to me" (Singh, S, K).

\subsection{Captain Harcharan Singh}

He was born to a poor Sikh, Aya Singh, in 1986. In 2007, he got a commission in Pakistan Army, but Captain Singh's father was not alive to see it. Captain Harcharan Singh was given a commission in Ordnance Corps, however, he has recently joined the senior and historical Fighter Baloch Regiment.

\subsection{Other Fields}

In Cricket, Anil Dulpat and Danish Kaneria and on platforms, such as UN, names like Zafarullah Khan are practical examples to whom the International court of Justice, which is in The Hague, Holland, became Vice President. After becoming a part of the world's largest and most respected court, he illustrated the name of Pakistan. Dr Abdul Salam was given the Nobel Prize in Physics.The world does not know him as a Qadiani, but as a Pakistani, minorities are not considered as tenants, they are also loyal sons of this country who have presented their blood to the country. These few examples of loyalty are a milestone for the promotion of religious harmony in the Pakistani nation, and are sufficient to moderate the path in Pakistani society. By following Pakistan's Constitution non-Muslims are not only loyal to Pakistan but are also sincere soldiers of the country.

\section{Future Recommendations}

- Appropriate measures should be adapted for broadcasting and implementation of quotas allocated to non-Muslim citizens for government jobs, so that the created misunderstandings can be put to an end in time.

- Capacity building programs should be initiated to enhance their capabilities via training and skill development initiatives. Good relations need to be established with non-Muslim population residing in Pakistan for promoting interfaith harmony.

- Muslim and non-Muslim dialogue forums should be established for eliminating the feeling of deprivation from their hearts. Members from different Pakistani NGOs should be trained for dialogue and confidence building between different religious groups.

- An independent and permanent commission should be established for non-Muslim citizens living in Pakistan responsible for conducting neutral inquiries for religious extremists so that the culprits should be exposed as soon as possible.

- Furthermore, consultation of non-Muslims in certain laws is of utmost importance, similarly, for Hindus and Sikhs, priority should be given to amendments in the rules and regulation and this should be done in consultation with them.

\section{References}

"Aah Rana Bagwan Daas", Nwa e Waqt ,February 24, 2015.

"Aah Rana Bagwan Daas", Nwa e Waqt, Lahore, Pakistan ,February 24, 2015.

[A Tribute to this Country]. Prothom Alo (in Bengali). 3 November 2017

Akhtar, S.(1997). Tahreek e Pakistan k Gumnam kirdar, Christian Study Center Rawalpindi, pp. 85.

Akhtar,S .(1997). Tahreek e Pakistan k Gumnam kirdar, pp. 96.

Collins English Dictionary, Available at: , Accessed on: 15 October 2018.

Dadachan Ji, F.K. (1997).An Ancient and Modern, Parsis, Karachi. 
Dadchanji, F.K. (1997) Speeches andwritingonZorstrain Religion, culture andcivilization, pp. 320.

Dahlavi, S. A. (1898). Ferhang e Asfia, vol: 2, pp.168.

Dahlavi, S. A. (1898). Ferhang e Asfia. Matboa, Islamia Press, Lahore, vol: 4, pp. 652.

Encyclopedia Britannica. 17 (11th ed.). Cambridge University Press, pp. 8o.

Father-e-France, N. (1997). Ya Daas Hamara Ha, Ham Aahang Publishers, Sant Mirez Church, 7 D Gulbarg 11, Lahoor, Pakistan , pp. 171.

Gardsh e Aflaq", Nwa e Waqt, February 24, 2015.

Government of Pakistan, 1998, op, cit

Habeeb, H. (1995).SmajiKhidmat,( Translation, Ajmal) Samahi, "ج",pp. 263 -269.

http://urdu.abbtakk.tv/43440-stories-aaj-ka-din-justice-durab-patel-barsi150315/

Interview Shaikh Naveed Iqbal, Roznama Jang, Rawalpindi, Golden Jubli Especial, 21 August 1997

News Paper Jang, Lahoor, Golden Jublie, especial, 26 July, 1997.

Nsher,Q.(2008).Quaid e Azam Bhasiet e Sarbrah e Momlikt, Qlim, Publisher, Maktba Alia, , pp. 58-59.

Pakistan Hindu Council, retrieved , 28 July, 2014

Sahih al-BUkhari Hadith no:1886, vol: 3, pp.23

Salim, A. (2000). Pakistan Aor Aqliyatian, Maktba Daniyal, Wiktoria Chambers 2, Abdullah Haroon Road, Sadar, Karachipp.476,498.

Salim, A. (2000). Pakistan Aor Aqliyatian, PP: 481

Salim, A. (2000). Pakistan Aor Aqliyatian, pp. 481

Salim, A. (2000). Pakistan Aor Aqliyatian, pp.461, 493.

Salim, A. (2000). Pakistan Aor Aqliyatian, , pp. 101.

Salim,A. (2000). Pakistan Aor Aqliyatian, pp.465, 473.

Serhanddi,W. (1983). Ilmi Urdu Lughat, , Ilmi Kutab Khana, Lahore, Pakistan, pp. 1591.

Singh, S, K. Sachi Sakhi, (Goor Mokhi), pp. 144

The constitution of the Islamic republic of Pakistan as Modified up to the 30 March, 2017, Third

Schedule: pp. 185, 186, 197, 200.

The constitution of the Islamic republic of Pakistan as Modified up to the 30 March, 2017, National Assembly of Pakistan, Art:27

The constitution of the Islamic republic of Pakistan as Modified up to the 30 March, 2017, National Assembly of Pakistan, Art:244.

The constitution of the Islamic republic of Pakistan as Modified up to the 30 March, 2017, National Assembly of Pakistan, Art:245.

The constitution of the Islamic republic of Pakistan as Modified up to the 30 March, 2017, National Assembly of Pakistan, Art:39.

The constitution of the Islamic republic of Pakistan as Modified up to the 30 March, 2017, National Assembly of Pakistan, Art: 5 .

The constitution of the Islamic republic of Pakistan, Article 5

The News International, Jang Group of Newspapers, 2010. 